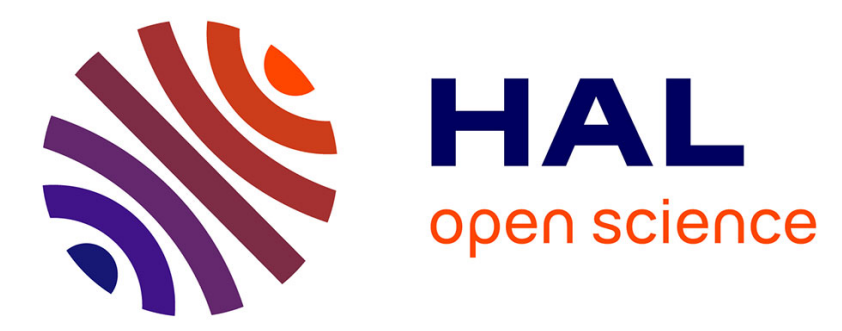

\title{
Salt and aroma compound release in model cheeses in relation to their mobility
}

Clementine Lauverjat, Isabelle Délérist, Cristian Trelea, Christian Salles, Isabelle Souchon

\section{- To cite this version:}

Clementine Lauverjat, Isabelle Délérist, Cristian Trelea, Christian Salles, Isabelle Souchon. Salt and aroma compound release in model cheeses in relation to their mobility. Journal of Agricultural and Food Chemistry, 2009, 57 (21), pp.9878-9887. 10.1021/jf901446w . hal-01195432

\section{HAL Id: hal-01195432 \\ https://hal.science/hal-01195432}

Submitted on 31 May 2020

HAL is a multi-disciplinary open access archive for the deposit and dissemination of scientific research documents, whether they are published or not. The documents may come from teaching and research institutions in France or abroad, or from public or private research centers.
L'archive ouverte pluridisciplinaire HAL, est destinée au dépôt et à la diffusion de documents scientifiques de niveau recherche, publiés ou non, émanant des établissements d'enseignement et de recherche français ou étrangers, des laboratoires publics ou privés. 


\title{
Salt and Aroma Compound Release in Model Cheeses in Relation to Their Mobility
}

\author{
Clémentine Lauverjat, ${ }^{\dagger}$ Isabelle Déléris, ${ }^{\dagger}$ Ioan Cristian Tréléa, ${ }^{\dagger}$ \\ Christian Salles, ${ }^{\S}$ and Isabelle Souchon $*, \dagger$ \\ †UMR 782 Génie et Microbiologie des Procédés Alimentaires, AgroParisTech - INRA, B.P. 1, \\ 1 Avenue Lucien Brétignières, 78850 Thiverval-Grignon, France, and ${ }^{\S}$ UMR 1129 Flaveur Vision \\ Comportement du consommateur, INRA - ENESAD - Université de Bourgogne, 17 Rue de Sully, \\ 21000 Dijon, France
}

\begin{abstract}
Physicochemical properties (partition and diffusion coefficients) involved in the mobility and release of salt and aroma compounds in model cheeses were determined in this study. The values of $\mathrm{NaCl}$ water/product partition coefficients highlighted interactions between proteins and $\mathrm{NaCl}$. However, these interactions were not modified by the product composition or structure. On the contrary, model cheese composition and structure influenced $\mathrm{NaCl}$ diffusion and both partition and diffusion for aroma compounds. Analysis of in-nose measurements of aroma release during eating, with regard to physicochemical properties, showed that product and aroma properties partly contributed to flavor release. Depending on the model cheese composition, structure and firmness, physicochemical properties, food breakdown, and chewing behavior can lead to different aroma release profiles. Finally, a discussion of all the results with regard to salt and flavor perception of the model cheese showed that both physicochemical and cognitive mechanisms contributed to perception.
\end{abstract}

KEYWORDS: NaCl; volatile compounds; partition coefficient; diffusion coefficient; nose-space analysis; PTR-MS; lipoproteic matrix

\section{INTRODUCTION}

The daily consumption of salt in developed countries is too high and contributes to health issues such as hypertension, coronary disease, and stroke. For example, French salt consumption ranges from 9 to $10 \mathrm{~g} / \mathrm{day}$, whereas the daily recommended allowance is around $6-8 \mathrm{~g}(1)$. Consequently, there is an increasing interest in the production of low-sodium food products. However, because salt perception interacts with aroma perception (2), the reduction of salt in food products without modifying their organoleptic properties requires a better understanding of the effects of food structure and composition and of oral processes on aroma and salt release and perception. During food consumption, the release of stimuli such as salt and aroma compounds contributes to perception and depends on physicochemical properties such as saliva/product (salt) or air/product (aroma compound) partition and diffusion. The determination of these two properties, associated with a better understanding of the influence of food composition and structure, is thus needed to obtain a better understanding of the mechanisms involved in release and perception. These two physicochemical properties for aroma compounds have been the subject of many studies. The determination of air/product partition coefficients notably highlights the retention effect of proteins (3) and fat (4) on aroma compounds. On the contrary, the addition of salt may lead to an increase in the air/product partition coefficient of

*Corresponding author [telephone +33 (0)1 308154 86; fax +33 (0)1 308155 97; e-mail souchon@grignon.inra.fr]. aroma compounds $(5,6)$. Food structure influences kinetic parameters such as the diffusion coefficient. Whether in simple gels such as pectin or in carrageenan gels $(7,8)$ or complex products such as yogurt (9), the presence of a complex tridimensional network leads to a decrease in the diffusion coefficient of aroma compounds. Concerning $\mathrm{NaCl}$, these two properties have been less studied. The $\mathrm{NaCl}$ diffusion coefficient has been mainly determined during the brining or ripening step to predict the final concentration of $\mathrm{NaCl}$ in cheeses $(10,11)$ or meat products (pork, fish) $(12,13)$ and the time required to obtain this concentration. The impact of food structure on $\mathrm{NaCl}$ diffusion was highlighted: the increase in dry matter or fat content increased the sieving effect of the structure and decreased the diffusion coefficient of $\mathrm{NaCl}(10,14)$. The water/product partition coefficient of $\mathrm{NaCl}$ has also received little attention. To our knowledge, only two studies have dealt with the determination of the $\mathrm{NaCl}$ water/ product partition coefficient $(15,16)$, and the influence of product composition has not yet been tackled.

Stimulus release depends on partition and diffusion properties. However, during eating, it also depends on the type of foods (liquid/solid), on how the food matrix is manipulated in the mouth before being swallowed, and on physiology. Several authors have highlighted the role of physiological parameters on volatile release, notably respiratory rate, masticatory parameters (17), or the velum-tongue border (18). The effectiveness of this physiological barrier depends on food texture and amount: for liquid food products, aroma transport to the nose can only occur during the swallowing breath when a direct connection 
between oral and nasal cavities exists. For solid food products, mastication can induce intermittent opening of the connection, leading to aroma release in the nasal cavity before the swallowing event $(18,19)$. Mastication causes the disorganization of the matrix and the mixing of food particles with saliva, modifying the transfer interface between the product and the oral cavity where the volatile compounds are released (20). In-nose measurement techniques such as atmospheric pressure ionization-mass spectrometry (API-MS) and proton transfer reaction-mass spectrometry (PTR-MS) are available today to measure aroma release in the expired air of a subject during food consumption. Using these techniques, the impact of food structure and texture on aroma release has been studied in different types of products but results were not always in agreement, and three tendencies emerged. First, some authors observed that the increase in product viscosity or firmness induced a decrease in flavor release $(21,22)$. On the contrary, studies showed that when the firmness of pectin gels, gelatin gels, or model cheeses increased, the quantity of released aroma compounds increased (23-25). Finally, some authors did not observe any modification in the release of flavor compounds in relation to changes in product structure $(26-28)$. These different findings have been attributed to differences in chewing behavior and in the experimental protocol used $(23,24)$. The main objective of all these studies was to explain perception. Some studies showed that flavor perception can be partly explained by the air/product partition coefficient $(29,30)$ and/or by flavor release $(31,32)$. However, some authors observed a decrease in flavor perception despite there being no difference in flavor release during consumption $(26,27)$. On the basis of statistical correlations, they concluded that an interaction between texture and flavor perceptions exists because perception is a very complex process. Sensory interactions between taste and flavor perception may also influence perception $(33,34)$. With regard to $\mathrm{NaCl}$ release and salt perception, it was shown that when $\mathrm{NaCl}$ release increased, salt perception increased as well $(34,35)$. However, this phenomenon has not yet been sufficiently linked to release mechanisms such as stimulus mobility in the food matrix or breakdown in the mouth.

Within this complex scientific context, the aim of the present study was first to determine the physicochemical properties (partition and diffusion coefficients) of both salt and aroma compounds in model cheeses with different textures and compositions. The release of aroma compounds during the consumption of model cheeses was then measured using a proton transfer reaction mass spectrometer. Finally, all of the results obtained were analyzed to identify the main mechanisms involved in the release and perception of salt and aroma compounds.

\section{MATERIALS AND METHODS}

Product Preparation. Model cheeses were prepared as described by Saint-Eve et al. (36): ultrafiltered skim milk retentate powder (Triballat, Noyal-sur-Vilaine, France), anhydrous milk fat (Corman, Goé, Belgium), and sodium chloride (Prolabo, France) were mixed together. Once the $\mathrm{pH}$ value had reached 6.2 by the addition of glucono- $\delta$-lactone (SigmaAldrich, Steinheim, Germany), rennet was added and the mix was poured into different containers (depending on the method used for the determination of salt and aroma compound properties) for a $3 \mathrm{~h}$ coagulation step. Ultrafiltered skim milk retentate powder was used because its mineral composition was quite similar to that of cow's milk and it made it possible to avoid the usual syneresis phenomenon. Model cheeses were stored at $4{ }^{\circ} \mathrm{C}$ until experiments were carried out the day after their preparation. Six model cheeses were studied, varying in fat content ( 20 or $40 \%$, dry basis), initial salt content $(0.5$ or $1.5 \% \mathrm{w} / \mathrm{w})$, or dry matter $(250,370$, or $440 \mathrm{~g} / \mathrm{kg})$. Products were coded as follows: dry matter-fat content (dry basis)-salt content. As shown in Table 1, the variation of the composition led to model cheeses with various degrees of firmness (evaluated by texture profile
Table 1. Premix Composition of the Seven Cheese Models ${ }^{a}$

\begin{tabular}{lcccc}
\hline matrix $(w-x-y)$ & $\begin{array}{c}\text { dry matter } \\
(\mathrm{g} / \mathrm{kg})\end{array}$ & $\begin{array}{c}\text { anhydrous milk } \\
\text { fat [fat/dry matter } \\
(\% \text { in w/w })]\end{array}$ & $\begin{array}{c}\mathrm{NaCl} \\
(\% \text { in w/w })\end{array}$ & $\begin{array}{c}\text { firmness } \\
(\mathrm{TPA})(\mathrm{N})\end{array}$ \\
\hline $250-40-1.5$ & 250 & 40 & 1.5 & 1.23 \\
$370-20-0.5$ & 370 & 20 & 0.5 & 5.31 \\
$370-20-1.5$ & 370 & 20 & 1.5 & 3.82 \\
$370-40-0.5$ & 370 & 40 & 0.5 & 2.82 \\
$370-40-1.5$ & 370 & 40 & 1.5 & 2.54 \\
$440-40-0.5$ & 440 & 40 & 0.5 & 6.13 \\
\hline
\end{tabular}

${ }^{a} w$, dry matter content; $x$, fat content; $y$, salt content.

Table 2. Physicochemical Properties of Aroma Compounds Used To Flavor Model Cheeses and Final Concentrations

\begin{tabular}{|c|c|c|c|c|c|c|}
\hline $\begin{array}{c}\text { aroma } \\
\text { compound }\end{array}$ & formula & $\begin{array}{c}\mathrm{mol} \mathrm{wt} \\
\left(\mathrm{g} \mathrm{mol}^{-1}\right)\end{array}$ & $\begin{array}{c}\text { concn in } \\
\text { model } \\
\text { cheese } \\
(\mathrm{mg} / \mathrm{kg})\end{array}$ & $\log P^{a}$ & $\begin{array}{l}\text { sensory } \\
\text { aroma } \\
\text { attribute }\end{array}$ & $\begin{array}{l}K_{\text {gas/water }} \\
\left(25^{\circ} \mathrm{C}\right)^{a}\end{array}$ \\
\hline diacetyl & $\mathrm{C}_{4} \mathrm{H}_{6} \mathrm{O}_{2}$ & 86 & 130 & -1.34 & butter & $0.072 \times 10^{-2}$ \\
\hline $\begin{array}{l}\text { ethyl } \\
\text { hexanoate }\end{array}$ & $\mathrm{C}_{8} \mathrm{H}_{16} \mathrm{O}_{2}$ & 144 & 9 & 2.83 & $\begin{array}{l}\text { fruity, } \\
\text { pineapple }\end{array}$ & $3.35 \times 10^{-2}$ \\
\hline heptan-2-one & $\mathrm{C}_{7} \mathrm{H}_{14} \mathrm{O}$ & 114 & 6 & 1.98 & blue cheese & $0.57 \times 10^{-2}$ \\
\hline
\end{tabular}

${ }^{a} \log P=\operatorname{logarithm}$ of the ratio of the compound concentration in octanol and in water (EPI, 2000, Estimation Programs Interface V3, 10: database).

analysis as described by Saint-Eve et al. (36)). For diffusion experiments and in-nose measurements, products were flavored to $0.1 \%(\mathrm{w} / \mathrm{w})$ with a blue cheese flavor containing diacetyl ("buttery" note), heptan-2-one ("blue cheese" note), and ethyl hexanoate ("fruity" note) mixed with propylene glycol (Aldrich, France). The flavoring step was performed before rennet addition in the preparation of model cheeses. The three aroma compounds were provided by Aldrich (Germany). Their physicochemical properties and their final concentrations in the product are listed in Table 2.

Measurement of Aroma Compound Release Kinetics. Aroma compound release kinetics were determined using the Volatile Air Stripping Kinetic method (VASK) (37). Figure 1 represents the diagram of the experimental assembly used in the VASK method. This method is based on the measurement of the evolution of aroma compound gaseous concentration above a layer of product when a gaseous flow rate is applied. Twenty-five grams of flavored matrix was gelled in $250 \mathrm{~mL}$ flasks (Schott, France) and placed in a thermostated vault at $13{ }^{\circ} \mathrm{C}$ for $12 \mathrm{~h}$ to reach a thermodynamic equilibrium between the product and the headspace. The flask was connected to a high-sensitivity proton transfer reaction mass spectrometer (PTR-MS) (Ionicon Analytik, Innsbruck, Austria). The PTR-MS technique has already been largely described $(38,39)$. The PTR-MS instrument drift tube was thermally controlled $\left(60{ }^{\circ} \mathrm{C}\right)$ and operated at 2.0 mbar with a voltage of $600 \mathrm{~V}$. The ratio $E / N(E$ is the electric field and $N$ is the number density of the gas in the drift tube) was $154.0( \pm 0.4) \mathrm{Td}$ (Townsend; $\left.1 \mathrm{Td}=10^{-17} \mathrm{~V} \cdot \mathrm{cm}^{2}\right)$. Valves on vial caps made it possible to purge the headspace for $12 \mathrm{~min}$ with a constant air flow (from 20 to $40 \mathrm{~mL} / \mathrm{min}$ ), depending on the experiments. Measurements were performed with the MID mode with a dwell time per mass of $0.1 \mathrm{~s}$. The mass fragments for the studied compounds were as follows: $m / z 87$ (diacetyl), $m / z 115$ (heptan-2-one), and $m / z 145$ (ethyl hexanoate). The signal-to-noise ratio varied from 25 to $6 \times 10^{4}$, depending on the measured $\mathrm{m} / \mathrm{z}$, meaning that the responses for the three compounds sufficiently exceeded the baseline. In addition, the ions $m / z 21$ (signal for $\mathrm{H}_{3}{ }^{18} 0^{+}$) and $m / z 37$ (signal of the cluster $\mathrm{H}_{5} \mathrm{O}_{2}{ }^{+}$formation) were observed to monitor the performance of the instrument. The count rate of $\mathrm{H}_{2} \mathrm{O}-\mathrm{H}_{3} \mathrm{O}^{+}$was $0.91-2.62 \%$ of the count rate of $\mathrm{H}_{3}{ }^{16} \mathrm{O}^{+}$ions, which was $(4.1-5.4) \times 10^{6}$ count $\mathrm{s}^{-1}$ (calculated by multiplying the $\mathrm{H}_{3}{ }^{18} \mathrm{O}^{+}$signal with a constant (500) reflecting the isotope ratio between the species $\mathrm{H}_{3}{ }^{18} \mathrm{O}^{+}$and $\mathrm{H}_{3}{ }^{16} \mathrm{O}^{+}$). Four replicates were performed for each product.

Determination of the Air/Product Partition and Diffusion Coefficients of Aroma Compounds. Using experimental release kinetics, a mass transfer analysis was used to determine air/product partition and 


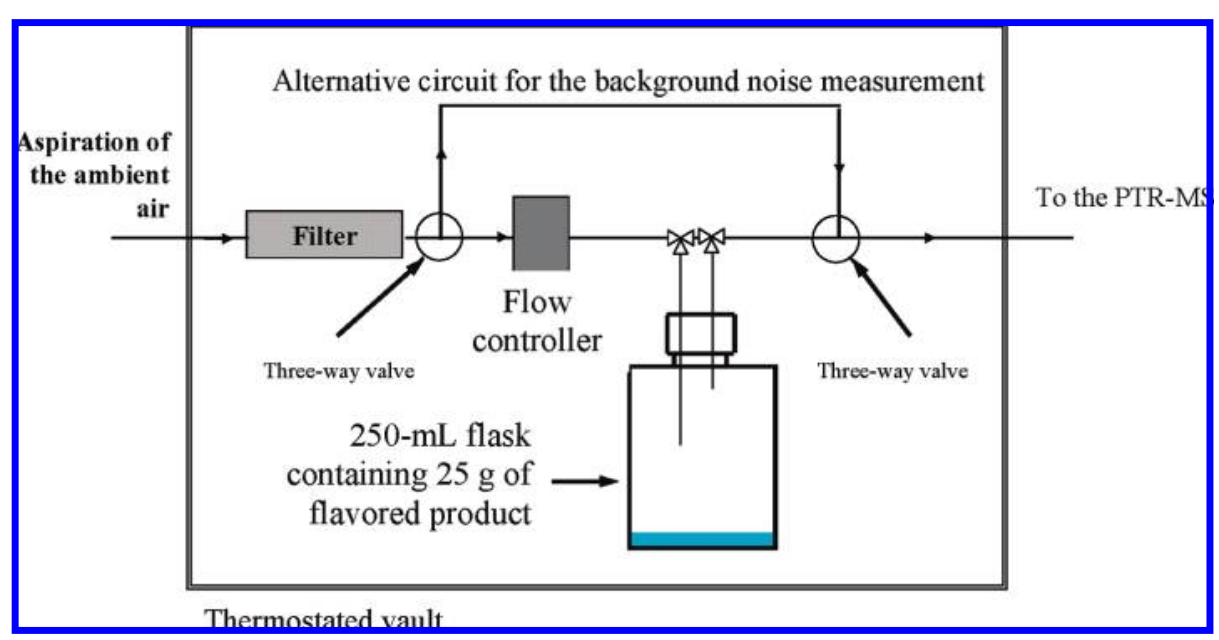

Figure 1. Diagram of the experimental assembly used in the Volatile Air Stripping Kinetic (VASK) method.

diffusion coefficients of aroma compounds. In the product, transport was considered unidirectional along the vertical axis and uniform on the cross section. The limiting step of aroma compound transfer was assumed to be the diffusion step within the product. The gaseous phase above the product was considered to be uniform, and convective mass transfer was assumed. Assuming a local thermodynamic equilibrium at the interfaces and mass flux conservation through the interfaces at any given time, mass balance on each phase was performed, leading to a mass transfer model. The apparent diffusion coefficient $D_{\mathrm{p}}$ and the air/product partition coefficient $K_{\mathrm{a} / \mathrm{p}}$ were determined by numerically fitting the mechanistic model to experimental release data using the Levenberg-Marquardt algorithm (least-squares curve fitting). Numeric calculations were performed using Matlab 7 software (The Mathworks, Natick, MA) and the associated statistics toolbox.

Determination of the Water/Product Partition Coefficient of $\mathrm{NaCl}$. The $\mathrm{NaCl}$ water/product partition coefficient, defined as the ratio of the equilibrium concentration of $\mathrm{NaCl}$ between the product and the water, was determined using the solid/liquid phase ratio variation (SL-PRV) as described by Lauverjat et al. (37). Seven bottles $(250 \mathrm{~mL}$, Schott, France) containing different volumetric ratios $(r)$ of salted matrix and deionized water were placed in a thermostated bath at $13{ }^{\circ} \mathrm{C}$ for $48 \mathrm{~h}$ to reach thermodynamic equilibrium between the water and the product. The product volume was between 10 and $40 \mathrm{~mL}$ and the water volume between 40 and $150 \mathrm{~mL}$. After $48 \mathrm{~h}$, the water conductivity was measured with a calibrated conductivity probe (Heito, France). For the sake of simplicity, the probe signal was attributed to both $\mathrm{NaCl}$ and the other electrolytes, referred to as X. An overall mass balance at equilibrium gave the probe signal $\left(S_{\mathrm{eq}}\right)$, calculated as

$$
S_{\mathrm{eq}}=\frac{[\mathrm{NaCl}]_{0}^{\mathrm{p}}}{r+1 / K_{\mathrm{NaCl}}}+\frac{[\mathrm{X}]_{0}^{\mathrm{p}}}{r+1 / K_{\mathrm{X}}}
$$

where $K_{\mathrm{NaCl}}$ and $K_{\mathrm{X}}$ are the partition coefficients of $\mathrm{NaCl}$ and $\mathrm{X}$, respectively, between water and the product matrix.

Because the conductivity signal was nonspecific, the determination of the $\mathrm{NaCl}$ partition coefficient required the preliminary estimation of the water/product partition coefficients of the other electrolytes $\left(K_{\mathrm{X}}\right)$ as well as the initial electrolyte concentration $[\mathrm{X}]_{0}^{\mathrm{p}}$. These parameters were determined using the same method used for unsalted matrices $\left([\mathrm{NaCl}]_{0}^{\mathrm{p}}=0\right.$ in eq 1).

A nonlinear regression as described by Atlan et al. (40) was used on the seven conductivity measurements to determine the electrolyte water/ product partition coefficient $\left(K_{\mathrm{NaCl}}\right.$ and $\left.K_{\mathrm{X}}\right)$ and the initial concentrations.

Determination of the Diffusion Coefficient of $\mathrm{NaCl}$. The $\mathrm{NaCl}$ diffusion coefficient was determined using the Solid/Liquid Nonvolatile Release Kinetic method (SL-NVRK) (37). This method is based on mass transfer analysis of solutes between the product and the liquid phase. To measure the release kinetics of $\mathrm{NaCl}$ from product to water, $40 \mathrm{~g}$ of model cheese was gelled in a $10 \mathrm{~cm}$ diameter beaker, leading to a product layer with $5.1 \mathrm{~mm}$ thickness. Five hundred milliliters of deionized water was added to the gelled product and stirred with a helix at $200 \mathrm{rpm}(\mathrm{Re}=$ $2 \times 10^{4}$ ). The stirring made it possible to maintain a turbulent flow in the water. A calibrated conductivity probe immersed in the water continuously measured the electrolytes released throughout the $48 \mathrm{~h}$, corresponding to thermodynamic equilibrium. Temperature was controlled and regulated at $13{ }^{\circ} \mathrm{C}$ with a thermostated bath.

The diffusion coefficients of $\mathrm{NaCl}\left(D_{\mathrm{NaCl}}\right)$ and of the other electrolytes $\left(D_{\mathrm{X}}\right)$ were determined using a mechanistic model based on mass transfer analysis. The main assumption was a limiting diffusive mass transfer of solutes $\mathrm{NaCl}$ and $\mathrm{X}$ within the product. The aqueous phase was considered to be uniform, and a convective mass transfer was assumed. Transport was considered to be one-dimensional along the vertical axis and uniform on the cross section. Assuming a local thermodynamic equilibrium at the water/product interface and mass flux conservation through the interface at any given time, mass balances for each phase were performed, leading to a mass transfer model.

To solve the model, a finite volume method was implemented. The space was discretized into 100 nodes. Numeric calculations in space and time were performed using Matlab 7 software (The Mathworks). The model adjustment to experimental conductivity data concerned diffusion coefficients of $\mathrm{NaCl}\left(D_{\mathrm{NaCl}}\right)$ and electrolytes $\left(D_{\mathrm{X}}\right)$. It was systematically verified that the reliable simultaneous determination of the two parameters was possible on the basis of the available measurements; the correlation between the estimated values remained low.

In-Nose Measurement of Aroma Compound Release. For in-nose analysis, a sampling device was placed in both of the subject's nostrils. This device was composed of two stainless steel pipes, each one adjustable in height and mobile enough to be adapted to the morphology of each subject. Air was drawn in at a rate of $30 \mathrm{~mL} / \mathrm{min}$ and introduced into the reaction chamber of the PTR-MS instrument through a heated $\left(60^{\circ} \mathrm{C}\right)$ Teflon transfer line. The ratio $E / N$ ( $E$ is the electric field and $N$ is the number density of the gas in the drift tube) was $150.6( \pm 1.2) \mathrm{Td}$ (Townsend; $1 \mathrm{Td}=10^{-17} \mathrm{~V} \cdot \mathrm{cm}^{2}$ ). The count rate of $\mathrm{H}_{2} \mathrm{O}-\mathrm{H}_{3} \mathrm{O}^{+}$was $3.1-3.5 \%$ of the count rate of $\mathrm{H}_{3}{ }^{16} \mathrm{O}^{+}$ions, which was $(4.3-5.5) \times 10^{6}$ count s$^{-1}$. The responses for the three compounds sufficiently exceeded the baseline (the signal-to-noise ratio varied from 8 to 12 depending on the measured $m / z$ ). Four experienced subjects (female, aged 25-34 years) participated in the in-nose analyses. All subjects underwent one training session, performing at least three practice runs prior to analysis to familiarize themselves with the protocol. The sessions ran over 4 weeks, two sessions per week, and each one lasted $45 \mathrm{~min}$. Eight replicates were performed by each panelist for each product. The samples were presented in a monadic way and were distributed using a Latin quare design for each assessor. After monitoring the air in the room for $10 \mathrm{~s}$, the assessors were asked to connect themselves to the sampling device and to breathe normally for $30 \mathrm{~s}$. After the absence of aroma compounds in the assessors' breaths had been verified, a $4 \mathrm{~g}$ portion of the product served at $13^{\circ} \mathrm{C}$ was taken into the mouth. No instructions were given to the assessors regarding how to consume the product. They were only asked to indicate with a beep every time they swallowed. The whole measurement lasted for 


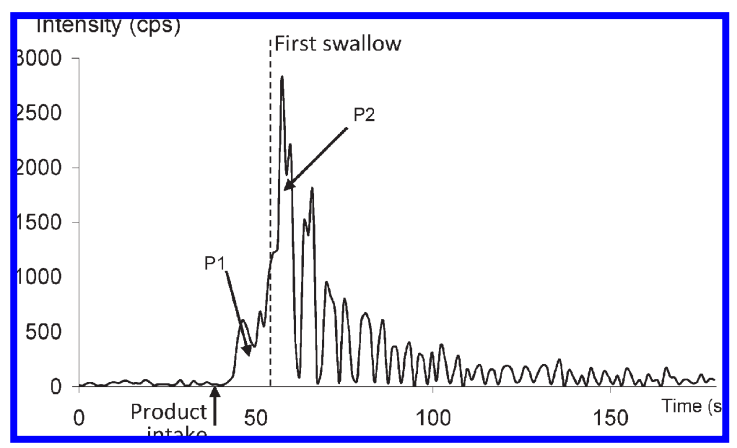

Figure 2. Example of a release curve obtained for diacetyl from the 370-20-1.5 model cheese when consumed by one subject using in-nose/PTR-MS analysis. P1 corresponds to phase 1, when the product was in the mouth, and P2 corresponds to phase 2, from the time the product is swallowed until the measurement ends.

$3 \mathrm{~min}$, and assessors were given water and plain crackers as a palate cleanser between samples. The $m / z$ values were the same as the ones monitored for in vitro measurements. In addition, the ion $\mathrm{m} / \mathrm{z} 59$, corresponding to breath acetone, was measured. In each session, six products were consumed by the assessors. Different parameters were extracted for each molecule from the raw PTR-MS data. The nose-space aroma release curves were divided into two phases. The first phase (P1) corresponded to the "oral" phase of consumption during chewing until swallowing, and the second phase (P2) corresponded to the phase after swallowing until the end time (Figure 2). For each phase of the release profile, calculated parameters involved the areas under the curves (AUC1 and AUC2) and the maximum intensities of the release profile $\left(I_{\max 1}\right.$ and $\left.I_{\max 2}\right)$. At the end of the second phase, the area under the last $10 \mathrm{~s}$ of the curve was calculated (S50-60).

Statistical Analysis. All data analyses were performed using the SAS software package, version 9.1 (41). Two different methods were used depending on the size of the sample. When the sample size was $>30$ items (in-nose measurement), an analysis of variance (ANOVA) was performed. Product effect (composition variable, subjects) was assessed by the two-way ANOVA. When the product effect was significant $(P<0.05)$, revealing a significant difference between the five products, a StudentNewman-Keuls (SNK) multiple-comparison test was performed to compare the product mean intensities. When the sample size was $<30$ items (physicochemical measurements), the Wilcoxon nonparametric test was performed.

The percentage of variation $(x)$ between the average intensity at the lowest level of each factor (Int. $x$ ) and the average intensity at the highest level of each factor (Int.y) was calculated according to the following formula:

$$
x(\%)=\left(\frac{\text { Int. } x-\text { Int. } y}{\text { Int. } y}\right) \times 100
$$

\section{RESULTS AND DISCUSSION}

The results of the evaluation of the influence of model cheese composition on the physicochemical properties of salt and aroma compounds and on in-nose flavor release are first presented. These results are then discussed in the last part to determine the respective role of physicochemical properties in solute release and perception.

Influence of Model Cheese Composition on the Water/Product Partition and Diffusion Coefficients of $\mathrm{NaCl}$. The partition coefficient can be defined as the solute affinity for the product. In this study, the $\mathrm{NaCl}$ water/product partition coefficient obtained using the SL-PRV varied from 0.66 to 0.83 (Figure 3). These values highlighted the existence of interactions between $\mathrm{NaCl}$ and the matrices because they were $<1$. Milk proteins, especially caseins, are known to bind to cations (42). This interaction takes place between the phosphoserine residue and the cation through

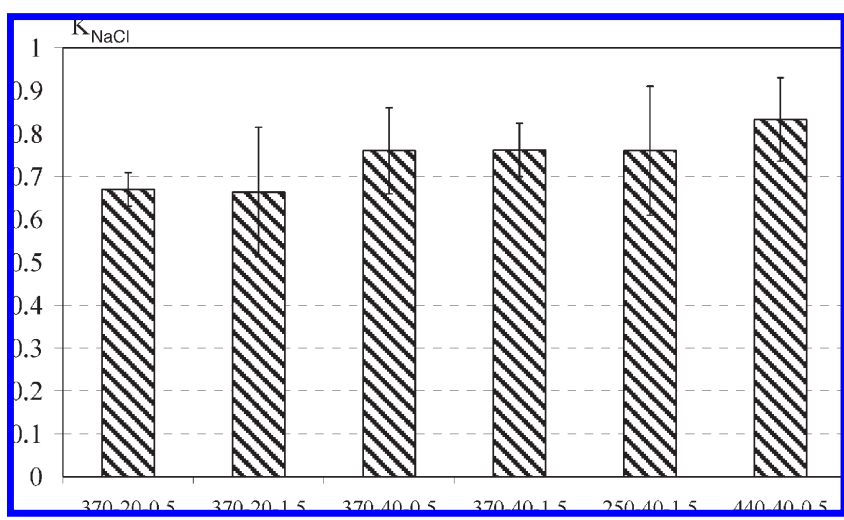

Figure 3. Water/product partition $\left(K_{\mathrm{NaCl}}\right)$ of $\mathrm{NaCl}$ in the model cheeses at $13^{\circ} \mathrm{C}$ (product code: dry matter ( $\left.\mathrm{g} / \mathrm{kg}\right)$ - fat content (\%)-salt (\%)). Bars represent $95 \%$ confidence intervals.

electrostatic bonds and depends on the protein (type of casein, charge), the cation (charge, size, hydration), and the environment $(\mathrm{pH}$, ionic strength, temperature). However, the standard deviation observed in Figure 3 showed that the composition had no significant influence on the partition coefficient value. The model cheeses studied contain several cations such as calcium, which is known to have a stronger affinity for casein than sodium (42). The modification of the composition would influence the caseincalcium interaction rather than the one between casein and sodium. This could explain why the variation of model cheese composition had no significant influence on the partition coefficient value, as illustrated in Figure 3.

The variation of model cheese composition, leading to different structures, influenced the diffusion coefficient because the values varied between $2.74 \times 10^{-10}$ and $9.11 \times 10^{-10} \mathrm{~m}^{2} / \mathrm{s}$. The dry matter content highly modified the diffusion coefficient of $\mathrm{NaCl}$ (Figure 4a). A 32\% decrease in the dry matter of the model cheeses (from 370 to $250 \mathrm{~g} / \mathrm{kg}$ ) led to an $80 \%$ increase in the diffusion coefficient. Moreover, the diffusion coefficient of $\mathrm{NaCl}$ in the 370-40-0.5 model cheese was $15 \%$ higher than the one of $\mathrm{NaCl}$ in the $440-40-0.5$ model cheese. The decrease in model cheese firmness (from 6.13 to $1.23 \mathrm{~N}$, Table 1) induced by a decrease in dry matter can partly explain the increase in the $\mathrm{NaCl}$ diffusion coefficient. The decrease in dry matter can also induce an increase in water available for $\mathrm{NaCl}$ transport and a decrease in the sieving effect of the protein networks. As already mentioned in previous works $(14,43)$, these two phenomena can influence $\mathrm{NaCl}$ diffusion.

Salt content also influenced the $\mathrm{NaCl}$ diffusion coefficient: a decrease in salt content from 1.5 to $0.5 \%$ led to a $40 \%$ decrease in the $\mathrm{NaCl}$ diffusion coefficients (Figure $\mathbf{4 b}$ ). This result can be explained by the modification in food structure induced by the variations in salt content.

With regard to fat content, the $\mathrm{NaCl}$ diffusion coefficients in high-fat model cheeses (370-40-0.5 and 370-40-1.5) were 12 and $17 \%$ higher, respectively, than in low-fat model cheeses (370-20-0.5 and 370-20-1.5) (Figure 4c). It would have been expected that an increase in fat content slowed the $\mathrm{NaCl}$ diffusion because of the sieving effect of fat globules (14). However, in the present case, the increase in fat content (dry basis) was correlated to a decrease in protein content, which seemed to facilitate $\mathrm{NaCl}$ diffusion.

Influence of Model Cheese Composition on Air/Product Partition and Diffusion Coefficients of Aroma Compounds. The VASK method led to the determination of both air/product partition and diffusion coefficients of aroma compounds in the model cheeses studied. Comparison of the different model cheeses made it 


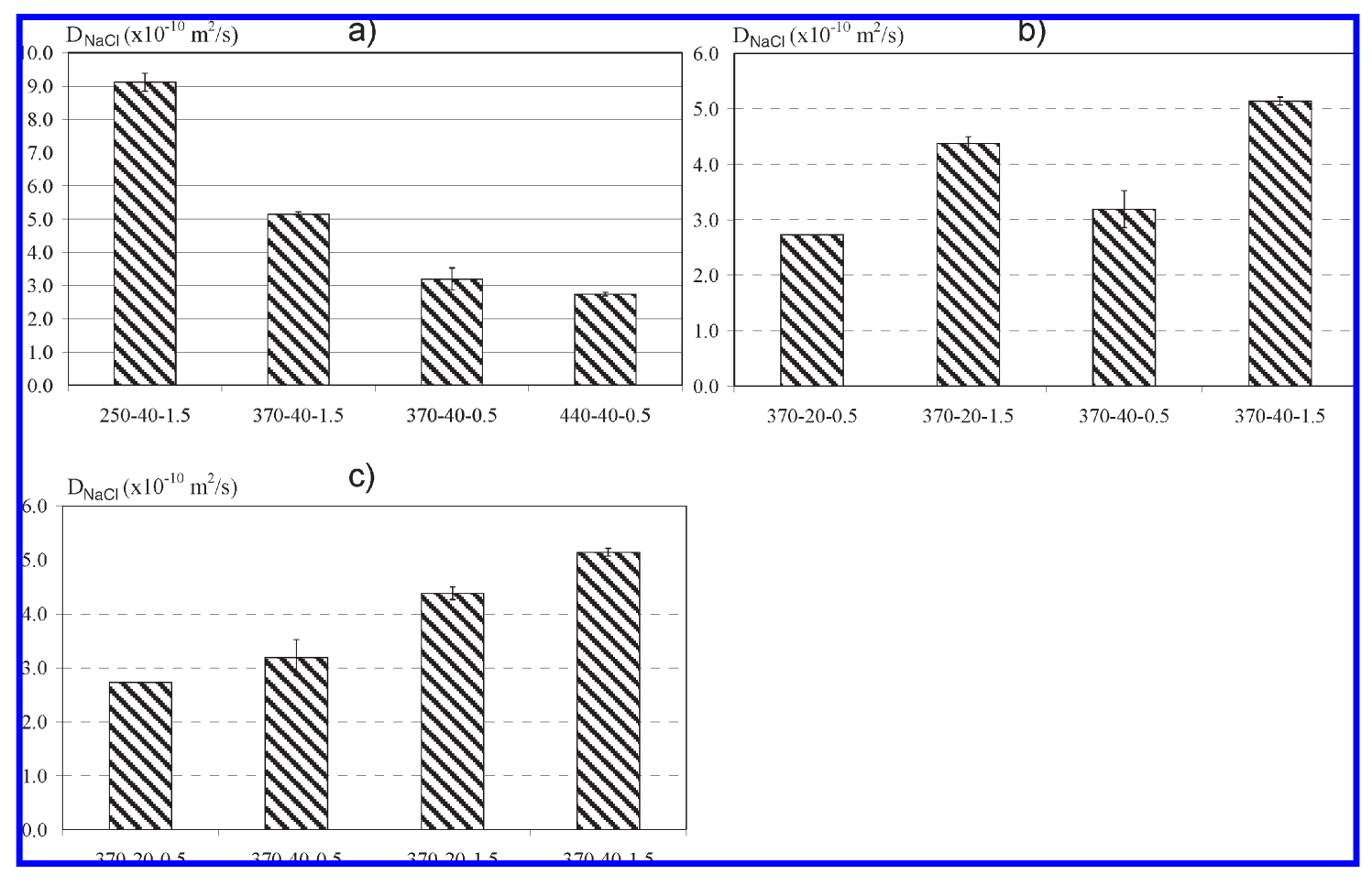

Figure 4. Influence of (a) dry matter content, (b) salt content, and (c) fat content on the diffusion coefficients $\left(D_{\mathrm{NaCl}}\right)$ of $\mathrm{NaCl}$ in the model cheeses at $13^{\circ} \mathrm{C}$ (product code: dry matter ( $\mathrm{g} / \mathrm{kg})$ - fat content $(\%)$-salt $(\%)$ ). Bars represent $95 \%$ confidence intervals.

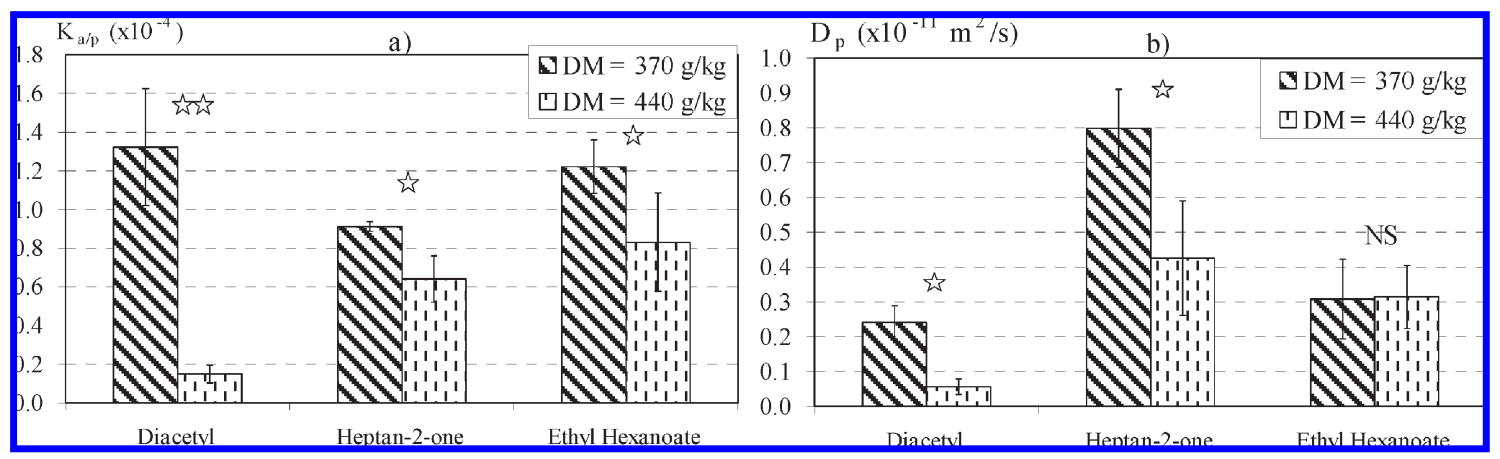

Figure 5. Influence of dry matter on (a) air/product partition $\left(K_{\mathrm{a} / \mathrm{p}}\right)$ and on (b) diffusion coefficients $\left(D_{\mathrm{p}}\right)$ of aroma compounds in model cheeses at $13^{\circ} \mathrm{C}$ (product code: dry matter ( $\mathrm{g} / \mathrm{kg})$ - fat content (\%)-salt (\%)). The number of asterisks indicates the level of significance: means significantly different at $P<$ 0.05 (*), at $P<0.01(* *)$, and $P<0.001(* * *)$. NS indicates that the results are not significantly different. Bars represent $95 \%$ confidence intervals.

possible to study the influence of product composition and structure on the two physicochemical properties (Figures 5, 6, and 7).

When the 370-40-0.5 and 440-40-0.5 model cheeses were compared, dry matter content significantly modified the two physicochemical properties, regardless of the aroma compound. An increase in dry matter induced a 30-90\% decrease in the air/ product partition coefficient, depending on the aroma compound (Figure 5a) and a 50-80\% decrease in the diffusion coefficient for heptan-2-one and diacetyl, respectively (Figure 5b). The decrease in the air/product partition coefficient of the three flavor compounds can be explained by the existence of hydrophobic interactions between proteins and aroma compounds (3). Diacetyl mainly interacts with sodium caseinate through weak and strong bonds between carboxyl groups of diacetyl and the terminal amino groups of proteins (44). The decrease in diffusion coefficients of diacetyl and heptan-2-one when dry matter content increased can be explained both by the protein-aroma compound interactions and by a tighter protein network that impedes the transport of aroma compounds.
With regard to fat content, comparison of 370-20-0.5 and $370-40-0.5$ or $370-20-1.5$ and $370-40-1.5$ model cheeses showed that regardless of the salt content, an increase in fat content (dry basis) induced a decrease in both the air/product partition coefficient (Figure 6a) and the diffusion coefficient (Figure 6b) of hydrophobic compounds (heptan-2-one and ethyl hexanoate). This result can be attributed to a retention effect of the lipid phase, which increases when fat content increases $(3,9,45)$. For diacetyl, which is much more hydrophilic, an increase in fat content slightly decreased the air/product partition coefficient in high-salt products and did not influence diffusion coefficients.

Finally, salt content mainly influenced the two properties involved in the mobility of ethyl hexanoate. An increase in salt content led to a $97 \%$ increase in the ethyl hexanoate air/product partition coefficient, probably due to the salting-out effect of sodium chloride on hydrophobic aroma compounds (Figure 7a). This headspace enrichment in volatile compounds resulting from salt addition has already been reported in the literature for aqueous solutions (3) and for dry-cured meat products (46) for high $\mathrm{NaCl}$ concentrations and seems to be dependent on the physicochemical properties of the 


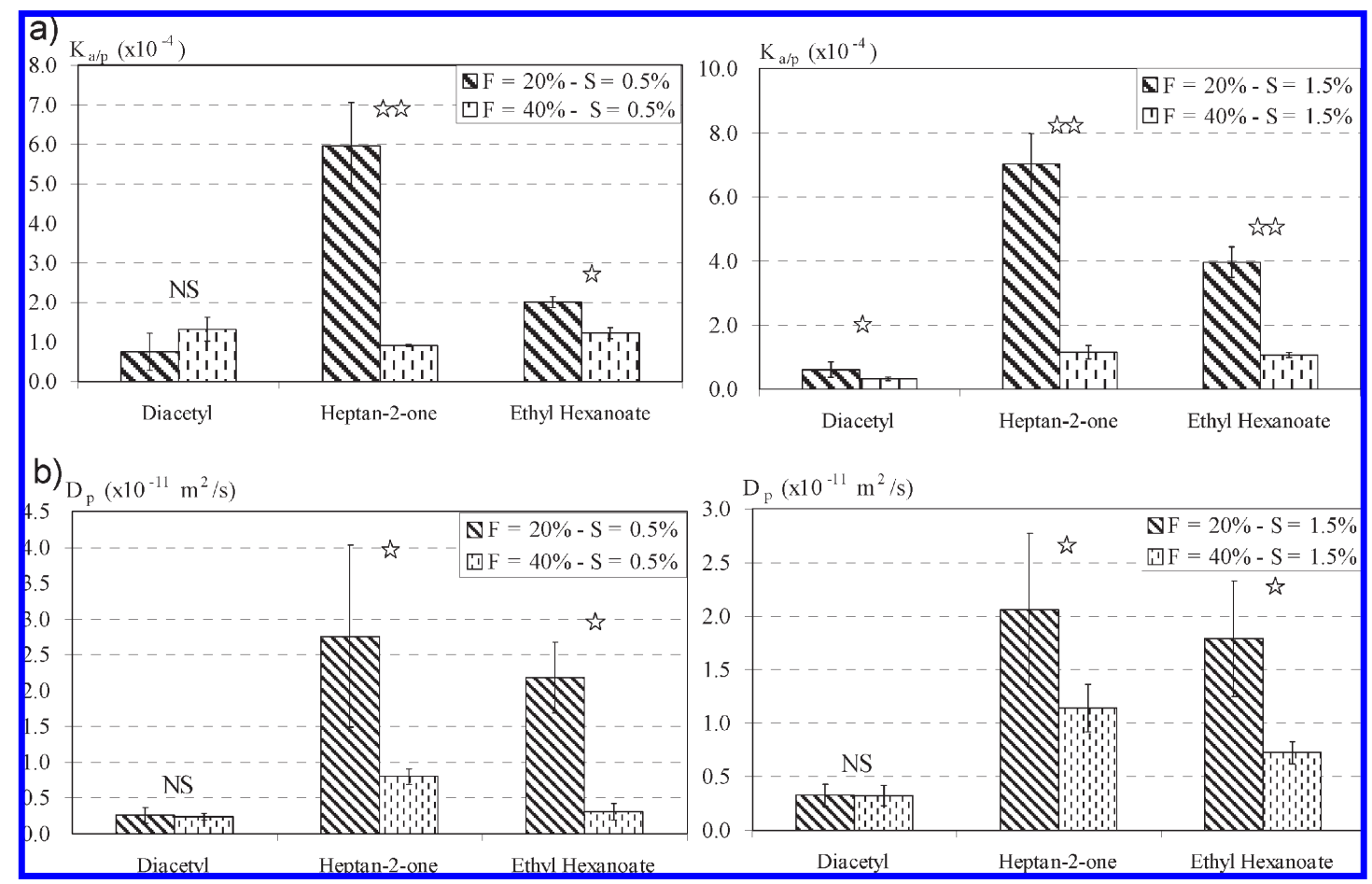

Figure 6. Influence of fat content on (a) air/product partition $\left(K_{\mathrm{a} / \mathrm{p}}\right)$ and on (b) diffusion coefficients $\left(D_{\mathrm{p}}\right)$ of aroma compounds in model cheeses at $13^{\circ} \mathrm{C}$ depending on $\mathrm{NaCl}$ content (product code: dry matter $(\mathrm{g} / \mathrm{kg})$ - fat content $(\%)-$ salt $(\%)$ ). The number of asterisks indicates the level of significance: means significantly different at $P<0.05(*)$, at $P<0.01(* *)$, and $P<0.001$ (***). NS indicates that the results are not significantly different. Bars represent $95 \%$ confidence intervals.

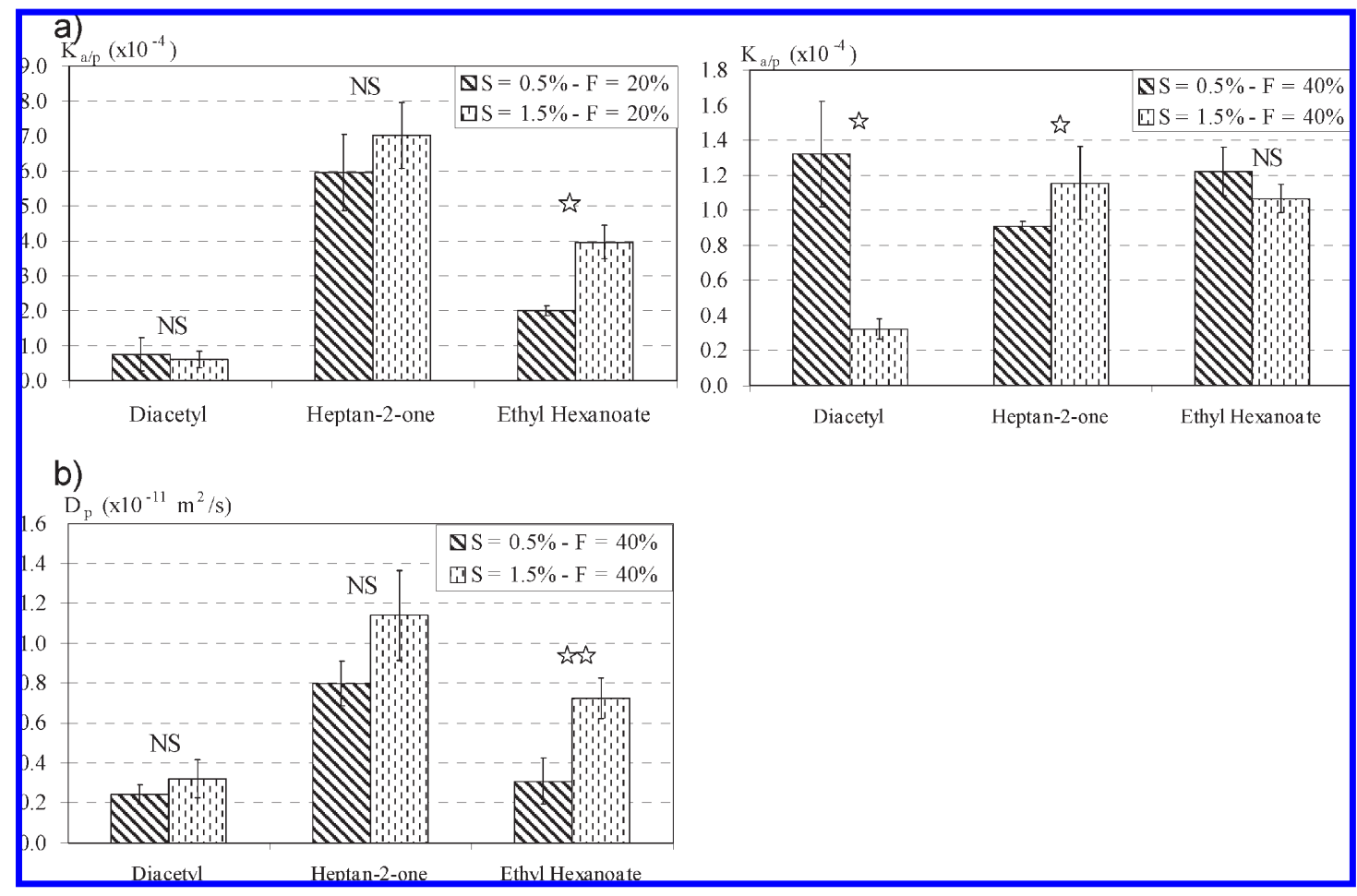

Figure 7. Influence of salt content on (a) air/product partition $\left(K_{\mathrm{a} / \mathrm{p}}\right)$ and on (b) diffusion coefficients $\left(D_{\mathrm{p}}\right)$ of aroma compounds in model cheeses at $13^{\circ} \mathrm{C}$ depending on fat content (product code: dry matter ( $\mathrm{g} / \mathrm{kg})$ - fat content $(\%)-$ salt $(\%)$ ). The number of asterisks indicates the level of significance: means significantly different at $P<0.05(*)$, at $P<0.01(* *)$, and $P<0.001(* * *)$. NS indicates that the results are not significantly different. Bars represent $95 \%$ confidence intervals.

compounds studied. A $1 \%$ increase in sodium chloride content (from 0.5 to $1.5 \%$ ) induced a $20 \%$ increase in the diffusion coefficient of ethyl hexanoate in high-fat model cheeses (Figure 7b). Because the diffusion of solutes is mainly influenced by structure (47), this increase can be attributed both to the decrease in model cheese firmness when salt content increases and to the salting-out effect of $\mathrm{NaCl}$. Salt content did not influence the diffusion coefficient in low-fat model cheese. 
Table 3. Average Values of the Area under the Release Curves before and after the First Swallow (AUC1 and AUC2, Respectively) of Model Cheeses That Vary by Their Composition with a 5\% Significance Determined by ANOVA

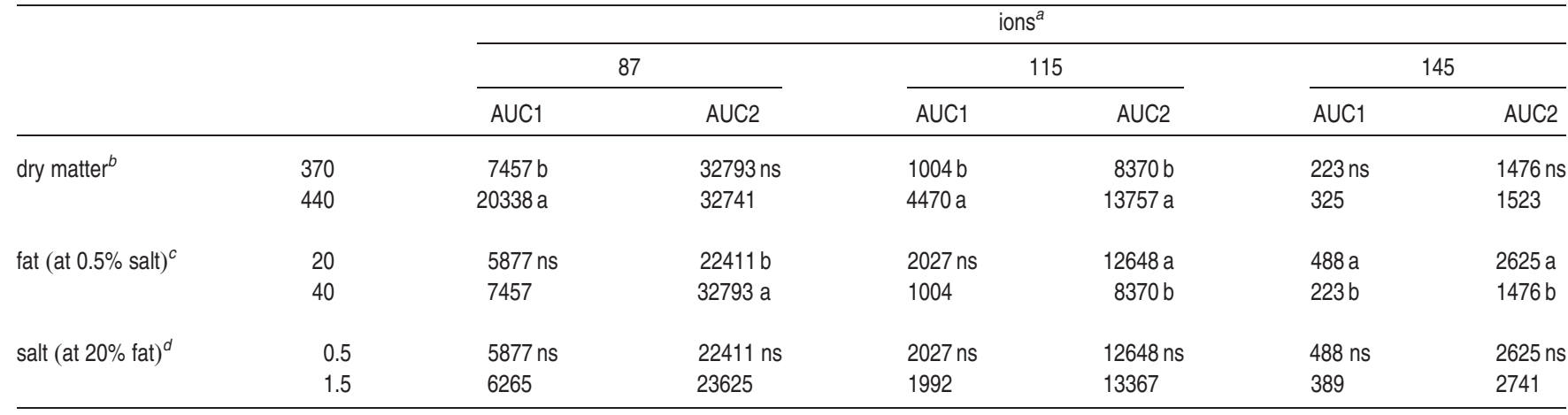

${ }^{a} a$ and $b$ indicate means that significantly differ at $p<0.05$ (SNK test), and NS indicates means that do not significantly differ. ${ }^{b}$ Between $370-40-0.5$ and $440-40-0.5$. ${ }^{c}$ Between $370-40-0.5$ and $370-20-0.5 .{ }^{d}$ Between $370-20-0.5$ and $370-20-1.5$.

Influence of Model Cheese Composition on Aroma Compound Release during Eating. As illustrated in Figure 3, the in-nose aroma release was greatest after swallowing: $I_{\max 2}$ and AUC2 values obtained during the second phase (after swallowing) were higher than $I_{\max 1}$ and AUC1 values obtained during the first phase (before swallowing) for all of the aroma compounds and for all of the subjects. The same observation has already been mentioned in different studies $(23,48)$. This phenomenon was attributed to the opening of the velum-tongue border during swallowing, allowing the transport of aroma compounds from the oral cavity to the nasal cavity $(18,19)$. Before swallowing, this physiological barrier is closed, even if intermittent and partial openings can occur, depending on the individuals and the structure and amount of the product. Comparison of the mean values of AUC before and after the first swallow (phases P1 and P2) made it possible to study the influence of product composition on aroma compound release while subjects were eating model cheeses (Table 3).

When dry matter increased, the release of diacetyl $(\mathrm{m} / \mathrm{z} 87)$ increased before the first swallow and the release of heptan-2-one $(m / z$ 115) increased before and after the first swallow (Table 3). Before swallowing, a less efficient closure of the velum-tongue border during chewing of the firmest food products can effectively lead to an increase in aroma release (18). An increase in the air/product exchange area for the firmest products due to a modification of the chewing behavior can explain the increase in aroma release after swallowing. We can, however, observe that these increases were much smaller after swallowing (64\% increase in heptan-2-one release) than before swallowing (170 and 350\% increase for diacetyl and heptan-2-one, respectively).

With regard to fat content, the results in Table $\mathbf{3}$ show that the released amounts of heptan-2-one $(m / z 115)$ and ethyl hexanoate ( $m / z$ 145) during the consumption of the high-fat model cheeses were lower than the ones released during the consumption of the low-fat model cheeses. On the contrary, when fat content increased, the release of diacetyl $(m / z 87)$ increased. These variations were greater after swallowing because only the release of ethyl hexanoate was significantly modified during the chewing phase (P1).

No significant differences in aroma compound release were observed during the consumption of model cheeses with different salt contents.

These results are discussed in relation to physicochemical properties in the following section.

Food Breakdown Rather than Mobility Explains Flavor Compound Release. In a first step, the influence of product composition and structure on flavor compound mobility was studied through the determination of the air/product partition and diffusion coefficients. The results showed that interactions between flavor compounds and model cheese components existed. The three aroma compounds interacted with proteins, leading to a decrease in both physicochemical properties involved in their mobility. Due to their hydrophobic characteristics, heptan-2-one and ethyl hexanoate are also trapped in the lipid phase. This well-known interaction induced a decrease in their air/product partition and diffusion coefficients. On the contrary, these two properties increased when salt content increased because of a combined effect of $\mathrm{NaCl}$ : a decrease in model cheese firmness and a saltingout effect. Thus, model cheese composition mainly influenced aroma compound mobility through physicochemical interactions. Beyond the flavor compound and product properties, eating is a complex process during which many phenomena occur and may influence the release of flavor compounds. According to Buettner and Schieberle (49), flavor release depends on the temperature in the mouth, the saliva and its $\mathrm{pH}$, and possible interactions with the mouth mucosa. In our study, two situations were observed. First, when the fat content increased, the influence of the interactions between the product and the flavor compounds on their mobility was great enough to decrease the release of aroma compounds in the mouth mainly after the first swallow. In this first case, the differences in mobility contributed to explain the release of flavor compounds during the consumption of model cheeses. The second case was observed when dry matter increased. Despite the existence of interactions between proteins and flavor compounds, their release highly increased during the chewing phase. This opposition between in vitro and in vivo measurements has already been observed in studies on custards (semiliquid product) or gels (solid product) $(23,50)$. In these studies, the greatest quantity of aroma compounds was released when the most viscous or the firmest products were consumed, whereas static headspace measurements showed the lowest release. The main assumption explaining these results, including ours, is based on the difference in experimental conditions between in vitro and in vivo experiments. When used for the determination of both properties involved in mobility (in vitro conditions), products were neither under stirring conditions nor fragmented. On the contrary, during consumption, products were stirred, fragmented, heated, diluted, etc. These phenomena lead to an increase in flavor release. Above all, mastication, which leads to a fragmentation of the product, increases the surface area between the product and the air of the nasal cavity available for mass transfer (51). In vivo studies showed that as the duration, frequency, and intensity of mastication increased, the higher the flavor release was $(49,52,53)$. In our study, subjects were free to swallow the product whenever they wanted, and no duration, strength, or frequency of mastication was imposed to the subject. Comparison of swallowing times showed that the firmer the 


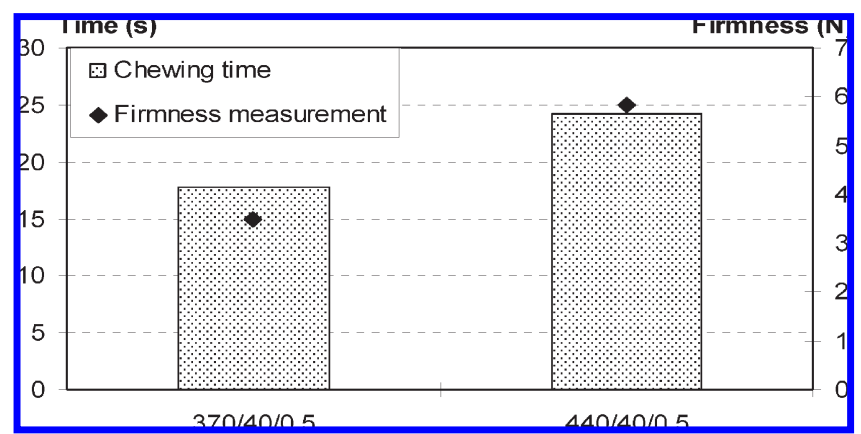

Figure 8. Relationship between the duration of the chewing phase and the firmness of the model cheeses (product code: dry matter $(\mathrm{g} / \mathrm{kg})-$ fat content (\%)-salt (\%)).

model cheese was, the longer the subject chewed it before swallowing (Figure 8). Similar results have already been observed with products with different textures $(23-25,54)$. Depending on their perception of the texture of model cheeses, subjects adapt their chewing behavior: rigid model cheeses implied the most extensive chewing and the highest residence time in the mouth, resulting in the highest release of volatiles (higher AUC values). Mastication induced food breakdown and thus increased the surface area available for the transfer of volatiles, which can contribute to the increase in the release of volatile compounds. In the present study, we showed that model cheese composition and structure influenced flavor release in different ways. When fat content varied, the main mechanism involved in aroma release was physicochemical and mainly influenced the second part of the release curves, that is, after the first swallow. On the contrary, when dry matter varied, inducing wide differences in model cheese firmness, the main mechanism in aroma release was mastication, which explained why it mainly influenced the first part of the release curve, that is, during the chewing phase.

Role of Solute Mobility and Release in Their Perception. In a previous study on the same model cheeses, differences in flavor perception were highlighted (36). First, an increase in fat content led to a decrease in the perception of the "blue cheese" note in the mouth. Variations in salt content induced an increase in the overall odor perception and a decrease in the butter note perception in mouth. Finally, no differences in flavor perception were observed when dry matter varied.

The relationship between flavor mobility or release and flavor perception has been widely observed in the literature $(21,22,50)$. In the present study, a decrease in heptan-2-one mobility and release in high-fat model cheese was observed. The increase in the overall odor perception when salt content increased was explained by the increase in air/product partition coefficients. Thus, the present study showed that product composition and structure influenced aroma compound mobility and release and, as a result, flavor perception.

However, some authors found that physicochemical properties cannot completely explain differences in perception (26-28), and other mechanisms such as sensory interaction may occur. The innose analysis performed in this study showed no difference in aroma release when salt content increased, whereas high-salt model cheeses were perceived as being less intense for the butter note than low-salt model cheeses. Sensory interactions between taste and flavor perception could explain the divergence we observed between perception and physicochemical properties when salt content increased, as already mentioned in the literature for savory agents such as salt or sugar $(31,55)$. In our study, the sensory interaction could possibly lead to a decrease in flavor perception. Taste-flavor sensory interactions are taste- or flavor-dependent, for example, between sugar perception and a strawberry flavor $(2,33)$. In our study, butter perception could be inversely related to the salt perception, which could explain the decrease in the perception of the butter note when salt content increased.

Texture-flavor interactions could also explain some perception results; the suppressive effect of texture perception on flavor perception has been already observed in the literature $(27,28,31)$. This sensory interaction has been attributed to the fact that the subject focused on texture perception rather than on flavor perception (56). When the dry matter of model cheeses increased, the release of the three flavor compounds increased but no difference in perceptions was observed (36). As shown in Figure 8, the high dry matter model cheese $(440-40-0.5)$ was chewed longest, implying that the subject was less attentive to flavor perception, resulting in a lower note.

Salt perception of the model cheeses studied was only modified by their $\mathrm{NaCl}$ content. The determination of the water/product partition coefficient of $\mathrm{NaCl}$ showed that interactions between $\mathrm{NaCl}$ and caseins exist. However, model cheese composition did not influence the water/product partition coefficient of $\mathrm{NaCl}$, implying that regardless of the composition, the bound quantity of $\mathrm{Na}^{+}$remained the same. Rosett et al. (57) observed that the binding of $\mathrm{Na}^{+}$to casein induced a decrease in salt perception in tomato soups. This decrease in perception was attributed to the fact that the quantity of $\mathrm{Na}^{+}$bound to casein could not contribute to salty perception. In the present study, each model cheese presented the same quantity of bound $\mathrm{Na}^{+}$, implying that salt release in the mouth during the consumption of model cheeses was similar. This could explain why dry matter and fat content did not modify salt perception. However, it would be necessary to confirm these similar salt releases during consumption with inmouth analysis.

The determination of partition coefficients of $\mathrm{NaCl}$ and of aroma compounds highlighted the existence of interactions between these solutes and model cheese components. Variations in composition and structure of the studied model cheeses did not influence the $\mathrm{NaCl}$ water/product partition coefficient, but they modified $\mathrm{NaCl}$ diffusion and aroma compound mobility. Analysis of the in-nose measurements showed that both physicochemical and physiological mechanisms were involved in flavor release. When fat content increased, physicochemical properties contributed to flavor release. On the contrary, when composition considerably influenced model cheese firmness, as in the case when dry matter content increased, mastication seemed to be the key parameter in release. Depending on the dominant mechanism, different parts of release curves were influenced. When physicochemical properties were dominant, flavor release was mainly modified after the first swallow, whereas when food breakdown was dominant, flavor release was mainly influenced during the chewing phase. These differences revealed the advantage of coupling flavor release measurements with sensory methods such as temporal dominance of sensations (58) rather than sensory profiling. Perception is in fact a dynamic process that cannot be transmitted with a static method such as sensory profiling. Coupling temporal dominance of sensations with innose measurement of flavor release would be of great interest for proposing solutions for the difficult flavoring step of healthier products.

\section{ABBREVIATIONS USED}

ANOVA, analysis of variance; API-MS, atmospheric pressure ionization mass spectrometer; $\mathrm{AUC1}$, area under the curve during phase 1 of the release curve; AUC2, area under the curve during 
phase 2 of the release curve; $D_{\mathrm{NaCl}}$, diffusion coefficient of $\mathrm{NaCl}$ in model cheeses; $D_{\mathrm{P}}$, diffusion coefficient of aroma compounds in model cheeses; DM, dry matter $(\mathrm{g} / \mathrm{kg})$; F, fat content ( $\%$ dry basis); $I_{\max 1}$, maximum intensity of PTR-MS signal during phase 1 of the release curve; $I_{\max 2}$, maximum intensity of PTR-MS signal during phase 2 of the release curve; $K_{\mathrm{a} / \mathrm{p}}$, air/product partition coefficient; $K_{\mathrm{NaCl}}$, water/product partition coefficient of $\mathrm{NaCl}$; $K_{\mathrm{X}}$, water product partition coefficient of electrolytes X; P1, first phase of the release curve, i.e., the chewing phase; P2, second phase of the release curve, i.e., after the first swallow; PTR-MS, proton transfer reaction mass spectrometer; $\mathrm{S}$, salt content $(\%, \mathrm{w} / \mathrm{w}) ; S_{\text {eq }}$, signal of the conductivity probe at equilibrium; SL-NVRK, solid/liquid nonvolatile release kinetic; SL-PRV, solid/liquid phase ratio variation; SNK, Student-Newman-Keuls test; S50-60, area under the last $10 \mathrm{~s}$ of the release curve; TPA, texture profile analysis; VASK, volatile air stripping kinetic.

\section{ACKNOWLEDGMENT}

We gratefully acknowledge D. Forest and R. Rosoamanana for their technical contribution.

\section{LITERATURE CITED}

(1) AFSSA. Report on Salt. Evaluations and Recommendations; 2002.

(2) Djordjevic, J.; Zatorre, R. J.; Jones-Gotman, M. Odor-induced changes in taste perception. Exp. Brain Res. 2004, 159, 405-408.

(3) Guichard, E. Interactions between flavor compounds and food ingredients and their influence on flavor perception. Food Rev. Int. 2002, 18, 49-70.

(4) De Roos, K. B. How lipids influence food flavor. Food Technol. 1997, $51,60-62$.

(5) Poll, L.; Flink, J. M. Aroma analysis of apple juice-influence of salt addition on headspace volatile composition as measured by gaschromatography and corresponding sensory evaluations. Food Chem. 1984, 13, 193-207.

(6) Rabe, S.; Krings, U.; Berger, R. G. Initial dynamic flavour release from sodium chloride solutions. Eur. Food Res. Technol. 2003, 218, 32-39.

(7) Juteau-Vigier, A.; Atlan, S.; Deleris, I.; Guichard, E.; Souchon, I.; Trelea, I. C. Ethyl hexanoate transfer modeling in carrageenan matrices for determination of diffusion and partition properties. $\underline{J}$. Agric. Food Chem. 2007, 55, 3577-3584.

(8) Rega, B.; Guichard, E.; Voilley, A. Flavour release from pectin gels: Effects of texture, molecular interactions and aroma compounds diffusion. Sci. Aliment. 2002, 22, 235-248.

(9) Deleris, I.; Lauverjat, C.; Trelea, I. C.; Souchon, I. Diffusion of aroma compounds in stirred yogurts with different complex viscosities. J. Agric. Food Chem. 2007, 55, 8681-8687.

(10) Geurts, T. J.; Walstra, P.; Mulder, H. Transport of salt and water during salting of cheese. I. Analysis of the process involved. Neth. Milk Dairv J. 1974, 28, 102-129.

(11) Turhan, M.; Kaletunc, G. Modeling of salt diffusion in white cheese during long-term brining. J. Food Sci. 1992, 57 (5), 1082-1085.

(12) Rora, A. M. B.; Furuhaug, R.; Fjaera, S. O.; Skjervold, P. O. Salt diffusion in pre-rigor filleted Atlantic salmon. Aquaculture 2004, 232, 255-263.

(13) Vestergaard, C.; Risum, J.; Adler-Nissen, J. Na-23-MRI quantification of sodium and water mobility in pork during brine curing. Sci. 2005, 69, 663-672.

(14) Guinee, T. P. Salting and the role of salt in cheese. Int. J. Dairv Technol. 2004, 57, 99-109.

(15) Djelveh, G.; Gros, J. B.; Bories, B. An improvement of the cell diffusion method for the rapid determination of diffusion constants in gels or foods. J. Food Sci. 1989, 54, 166-169.

(16) Zorilla, S. E.; Rubiolo, A. C. A model for using the diffusion cell in the determination of multicomponent diffusion coefficients in gels or foods. Chem. Eng. Sci. 1994, 49, 2123-2128.

(17) Pionnier, E.; Chabanet, C.; Mioche, L.; Le Quere, J. L.; Salles, C. 1. In vivo aroma release during eating of a model cheese: relationsships with oral parameters. J. Agric. Food Chem. 2004, 52, 557-564.
(18) Buettner, A.; Beers, A.; Hanning, C.; Settles, M. Observation of the swallowing process by application of videofluoroscopy and real-time magnetic resonance imaging-consequences for retronasal aroma stimulation. Chem. Senses 2001, 26, 1211-1219.

(19) Mestres, M.; Kieffer, R.; Buettner, A. Release and perception of ethyl butanoate during and after consumption of whey protein gels: relation between textural and physiological parameters. J. Agric. Food Chem. 2006, 54, 1814-1821.

(20) Harrison, M. Mathematical models of release and transport of flavors from foods in the mouth to the olfactory epithelium. In Flavor Release, 2000; Roberts, D. D., Taylor, A. J., Eds.; ACS Symposium Series 763; American Chemical Society: Washington, DC, 2000; pp 179-191.

(21) Baek, I.; Linforth, R. S. T.; Blake, A.; Taylor, A. J. Sensory perception is related to the rate of change of volatile concentration in-nose during eating of model gels. Chem. Senses 1999, 24, 155-160.

(22) Saint-Eve, A.; Martin, N.; Guillemin, H.; Semon, E.; Guichard, E.; Souchon, I. Flavored yogurt complex viscosity influences real-time aroma release in the mouth and sensory properties. J. Agric. Food Chem. 2006, 54, 7794-7803.

(23) Boland, A. B.; Delahunty, C. M.; van Ruth, S. M. Influence of the texture of gelatin gels and pectin gels on strawberry flavour release and perception. Food Chem. 2006, 96, 452-460.

(24) Gierczynski, I.; Laboure, H.; Semon, E.; Guichard, E. Impact of hardness of model fresh cheese on aroma release: in vivo and in vitro study. J. Agric. Food Chem. 2007, 55, 3066-3073.

(25) Tarrega, A.; Yven, C.; Sémon, E.; Salles, C. Aroma release and chewing activity during eating different model cheeses. Int. Dairy J. 2007.

(26) Hollowood, T. A.; Linforth, R. S. T.; Taylor, A. J. The effect of viscosity on the perception of flavour. Chem. Senses 2002, 27, 583-591.

(27) Mestres, M.; Moran, N.; Jordan, A.; Buettner, A. Aroma release and retronasal perception during and after consumption of flavored whey protein gels with different textures. 1. In vivo release analysis. J. Agric. Food Chem. 2005, 53, 403-409.

(28) Weel, K.; Boelrijk, A.; Alting, A.; Van Mil, P.; Burger, J.; Gruppen, H.; Voragen, A.; Smit, G. Flavor release and perception of flavored whey protein gels: perception is determined by texture rather than by release. J. Agric. Food Chem. 2002, 50, 5149-5155.

(29) Reiners, J.; Nicklaus, S.; Guichard, E. Interactions between $\beta$ lactoglobulin and flavour compounds of different chemical classes. Impact of the protein on the odour perception of vanillin and eugenol. Lait 2000, 80, 347-360.

(30) Shamil, S.; Wyeth, L. J.; Kilcast, D. Flavour release and perception in reduced-fat foods. Food Oual. Pref. 1992, 3, 51-60.

(31) Cook, D. J.; Linforth, R. S. T.; Taylor, A. J. Effects of hydrocolloid thickeners on the perception of savory flavors. J.Agric. Food Chem. 2003, 51, 3067-3072.

(32) Linforth, R. S. T.; Ingham, K. E.; Taylor, A. J. Time course profiling of volatile release from foods during the eating process. In Flavour Science: Recent Developments; Taylor, A. J., Mottram, D. S., Eds.; Royal Society of Chemistry: Cambridge, U.K., 1996; pp 361-368.

(33) Frank, R. A.; Byram, J. Taste-smell interactions are tastant and odorant dependent. Chem. Senses 1988, 13, 445-455.

(34) Phan, V. A.; Yven, C.; Lawrence, G.; Chabanet, C.; Reparet, J. M.; Salles, C. In vivo sodium release related to salty perception during eating model cheeses of different textures. Int. Dairv J. 2008, 18, 956-963.

(35) Neyraud, E.; Prinz, J.; Dransfield, E. NaCl and sugar release, salivation and taste during mastication of salted chewing gum. Phvsiol. Behav. 2003, 79 (4-5), 731-737.

(36) Saint-Eve, A.; Lauverjat, C.; Magnan, C.; Déléris, I.; Souchon, I. Reducing salt and fat content: Impact of composition, texture and cognitive interactions on the perception of flavoured model cheeses. Food Chem. 2009, 116, 167-175.

(37) Lauverjat, C.; De Loubens, C.; Déléris, I.; Tréléa, I. C.; Souchon, I. Rapid determination of partition and diffusion properties for salt and aroma compounds in complex food matrices. J. Food Eng. 2009, 93, 407-415.

(38) Lindinger, W.; Hansel, A.; Jordan, A. Proton-transfer-reaction mass spectrometry (PTR-MS): on-line monitoring of volatile organic compounds at pptv levels. Chem. Soc. Rev. 1998, 27, 347-354. 
(39) Hansel, A.; Jordan, A.; Holzinger, R.; Prazeller, P.; Vogel, W.; Lindinger, W. Proton-transfer reaction mass-spectrometry - online trace gas-analysis at the ppb level. Int. J. Mass Spectrom. 1995, 149, 609-619.

(40) Atlan, S.; Trelea, I. C.; Saint-Eve, A.; Souchon, I.; Latrille, E. Processing gas chromatographic data and confidence interval calculation for partition coefficients determined by the phase ratio variation method. J. Chromatogr., A 2006, 1110, 146-155.

(41) SAS User's Guide: Statistics, version 6; SAS Institute: Cary, NC, 1990.

(42) Gaucheron, F. Interactions caséines-cations. In Minéraux et Produits Laitiers; Gaucheron, F., Ed.; Tec\&Doc, Lavoisier: Paris, France, 2004; pp 219-280.

(43) Geurts, T. J.; Walstra, P.; Mulder, H. Transport of salt and water during salting of cheese. II. Quantities of salt taken up and of moisture lost. Neth. Milk Dairy J. 1980, 34, 229-254.

(44) Fares, K.; Landy, P.; Guilard, R.; Voilley, A. Physicochemical interactions between aroma compounds and milk proteins: effect of water and protein modification. J. Dairv Sci. 1998, 81, 82-91.

(45) Piraprez, G.; Herent, M. F.; Collin, S. Flavour retention by lipids measured in a fresh cheese matrix. Food Chem. 1998, 61, 119-125.

(46) Flores, M.; Gianelli, M. P.; Perez-Juan, M.; Toldra, F. Headspace concentration of selected dry-cured aroma compounds in model systems as affected by curing agents. Food Chem. 2007, 102, 488-493.

(47) De Roos, K. B. Effect of texture and microstructure on flavour retention and release. Int. Dairv J. 2003, 13, 593-605.

(48) Hansson, A.; Giannouli, P.; Van Ruth, S. The influence of gel strength on aroma release from pectin gels in a model mouth and in vivo, monitored with proton-transfer-reaction mass spectrometry. J. Agric. Food Chem. 2003, 51, 4732-4740.

(49) Buettner, A.; Schieberle, P. Influence of mastication on the concentrations of aroma volatiles-some aspects of flavour release and flavour perception. Food Chem. 2000, 71, 347-354.
(50) Van Ruth, S.; de Witte, L.; Rey Uriarte, A. Volatile flavor analysis and sensory evaluation of custard desserts varying in type and conentration of carboxylmethyl cellulose. J. Agric. Food Chem. 2004, 52, 8105-8110.

(51) Hills, B. P.; Harrison, M. Two-film theory of flavour release from solids. Int. J. Food Sci. Technol. 1995, 30, 425-436.

(52) Mayr, D.; van Ruth, S. M.; Mark, T. D. Evaluation of the influence of mastication on temporal aroma release of ripe and unripe bananas, using a model mouth system and gas chromatography-olfactometry. Eur. Food Res. Technol. 2003, 217, 291-295.

(53) Van Ruth, S. M.; Dings, L.; Buhr, K.; Posthumus, M. In vitro and in vivo volatile flavour analysis of red kidney beans by proton transfer reaction-mass spectrometry. Food Res. Int. 2004, 37, 785-791.

(54) Van Ruth, S.; Buhr, K. Influence of mastication rate on dynamic flavour release analysed by combined model mouth/proton transfer reaction-mass spectrometry. Int. J. Mass Spectrom. 2004, 239, 187-192.

(55) Lethuaut, L.; Weel, K. G. C.; Boelrijk, A. E. M.; Brossard, C. Flavor perception and aroma release from model dairy desserts. $\underline{\text { J. Agric. }}$ Food Chem. 2004, 52, 3478-3485.

(56) Gierczynski, I.; Laboure, H.; Guichard, E. In vivo aroma release of milk gels of different hardnesses: Inter-individual differences and their consequences on aroma perception. J. Agric. Food Chem. 2008, 56, 1697-1703.

(57) Rosett, T. R.; Kendregan, S. L.; Klein, B. P. Fat, protein, and mineral components of added ingredients affect flavor qualities of tomato soups. J. Food Sci. 1997, 62, 190-193.

(58) Labbe, D.; Schlich, P.; Pineau, N.; Gilbert, F.; Martin, N. Temporal dominance of sensations and sensory profiling: a comparative study. Food Oual. Pref. 2008, 20, 216-221.

Received for review April 30, 2009. Revised manuscript received September 4, 2009. Accepted September 10, 2009. This work was supported by the French National Food Research Program (PRA 2005) coordinated by C.S. 